\title{
Study on the Blending of College Chinese Teaching and Traditional Culture Education
}

\author{
Xiaolan Wei \\ Nanchang Institute of Science \&Technology, Nanchang Jiangxi 330108, China
}

Keywords: college Chinese teaching; traditional culture; education

\begin{abstract}
With the deepening of college Chinese teaching, Chinese in colleges has become an important carrier of traditional culture education, playing a significant role in traditional culture education. However, the present condition of combination between college Chinese with traditional culture education is not optimistic. Therefore, in order to enrich related study, this paper focuses on the penetration of deep national culture.
\end{abstract}

\section{Modern Value and Basic Contents of College Chinese Teaching and Traditional Culture Education}

The inheritance and innovation are always the major problems related to traditional culture's development. The development is not a simple "copy" of traditional culture, nor a complete divorcement from tradition, but realization of creative transformation and innovative development based on the inheritance of traditional culture. During the process, college students shoulder an important historical responsibility.

College Chinese teaching and traditional culture education in fact are processes of inheriting and innovating the traditional culture. To learn traditional culture knowledge and to understand its basic spirits are the beginning of college Chinese teaching and traditional culture education. Through the study of traditional culture knowledge, students are able to improve their understanding of inner spirits of Chinese excellent traditional culture. On this basis, it will realize the internalization of traditional culture spirits and enhance college students' ability to inherit and innovate traditional culture. In the process of cultivation, in combination with actual situation of times and practice, we should ceaselessly endow traditional culture with new time connotation and manifestation, and strengthen its vitality and attraction.

College Chinese teaching and traditional culture education are not only indispensable parts of college students' scientific and cultural quality, but also significant contents of their ideological and moral quality. The excellent traditional culture contains Chinese nation's unique thinking mode, value concept, code of conduct and moral standard which has an inestimable value for college students' humanistic spirit creation and cultivation of cultural quality.

During the process of Chinese teaching and traditional cultural education, by comprehending traditional culture, college students learn ideological philosophy, practice traditional skills, visit historical sites, cultivate sentiment and enhance the appreciation ability of beauty. All of these will lay solid foundation for them to pursue higher spiritual state, provide spiritual power to seek their own progress and promote them to upgrade life altitude.

College Chinese teaching and traditional cultural education will inevitably require the integration of excellent traditional culture with colleges' moral education, progress in moral education work and enhancement of pertinence and effectiveness of current moral education in colleges.

As we all know, traditional culture is a kind of ethical culture in a certain sense. It contains abundant moral education resources with strong moral appeal. For instance, the value orientation of taking virtues as the first and righteousness as the top; benevolent spirits with politeness and friendliness; life realm attaching importance to personality and integrity; life concept of hardworking, plain living and thriftiness. It is not only the guiding system of subjective behaviors, but also the power system of talent growth. It is helpful to guide college students to deal with the relationship between man and nature, between man and society, between man and himself, and then 
to promote personality perfection and enhance the individual moral realm.

Chinese traditional culture is a typical kind of ethical culture whose basic function is to educate people and contains abundant traditional moral resources of high quality.

(1) Vigorous and promising attitude towards life. Confucian vigorous and active life attitude stresses that when a person encounters difficulties and setbacks, he must not shrink back but to overcome them. Vigorousness refers to responsibility. The independent, vigorous and enterprising spirits as well as lofty senses of historical responsibility and mission are necessary life attitudes for contemporary college students.

(2) Self-cultivation, self-control and consistence with words. Self-cultivation means to keep one's mind in a peaceful state by improving one's cultivation and abandoning the interference of external bad factors. Self-control emphasizes self-discipline and makes words and behaviors match moral rules. Consistence with words means one's thinking and words should be consistent with his actions, which can be further extended to be the same outside and inside. It is a good personal cultivation that should be owned by contemporary college students.

(3) Value orientation of faithfulness and righteousness. Faithfulness means one should be loyal to his own nature and be trustworthy to others. Righteousness requires people to consider whether they have violated the social ethics and moral norms when they pursue material benefits. It is a correct value orientation that contemporary students should adhere to.

(4) Communication ethics with benevolence, filial piety, humility and courtesy. They are basic principles to deal with relationships among family members and even among people, which mainly means people should get along with each other with benevolence and kindness. We should be loving fathers, faithful sons, friendly older brothers, modest elder brothers and have respect for seniority. Humility and courtesy are important virtues for Chinese people to get on in the world which emphasize modesty, politeness and courtesy. It has a positive guiding significance for contemporary college students in dealing with interpersonal relationship.

On the basis of understanding and learning the knowledge of excellent traditional culture, college students "can not only identify with nation's excellent traditional culture from the bottom of heart, but also show highly confidence for their modern values and future development”. On one hand, it shows college students' recognition for excellent traditional culture. On the basis of certain cognition for Chinese excellent traditional culture, students produce heartfelt admiration which will turn to be sense of belonging and pride for national culture. On the other hand, students are able to dialectically treat foreign culture, actively absorb its strengths, constantly enrich and improve themselves and resist the erosion of foreign decadent culture. Thirdly, it is necessary to take a progressive and innovated way to deal with and learn excellent traditional culture, actively participate in the inheriting and innovating activities and spread the excellent traditional culture of Chinese nation.

\section{Realistic Predicament and Causes of College Chinese Teaching and Traditional Culture Education}

Realistic situation of college Chinese teaching and traditional culture education is not optimistic: a lack of enthusiasm in learning traditional culture, inadequate mastery of traditional culture knowledge, desalinated traditional values and weakened ability to practice traditional virtues.

College students have not enough learning enthusiasm and a comparatively low recognition degree for traditional culture, resulting into their lack of basic knowledge and common sense of traditional culture. Inadequate contact with traditional literature works, national traditional festivals and traditional folk culture lead into college students' superficial understanding of traditional cultural knowledge.

In dealing with public-private relations, there is a "selfless" requirement in our traditional culture. Some contemporary college students support that they pay for higher return. Some even exact profits blindly without dedication. Parts of students take themselves as the center, neglecting others' feelings and team consciousness.

When handling relationship between justice and interest, a majority of college students give up 
the idea of emphasizing justice, abandon interests, advocate the unification or even show the trend for ingratitude. A minority would rather lose their dignity than money. In daily life, there exists the phenomenon of hedonism among college students, in which students pursue materials and money but disregard humanity spirits and moral beliefs. Behind the desalination of college students' traditional values, we can figure out that modern college students have a disturbing level of ideology and morality, reflecting their inadequate stress to improve their own moral level.

The weakened ability to practice traditional virtues is firstly manifested in the college students' lack of social civilization, such as inappropriate words, rude behaviors, trampling on the lawn, running red lights, jumping the queue, ruining public property, shouting and so on.

The weakened ability to practice traditional virtue is also manifested in the absence of students' credit consciousness. In their daily life, some are not willing to fulfill their commitments, overlooking things agreed with other students or teachers. After signing the letter of commitment, some still cheat in the examination or even renovate cheating means.

The weakening of the ability to practice traditional virtue is reflected in the lack of social responsibility too. As a kind of moral emotion, responsibly refers to the moral duty that a person undertakes for the country, the collective and others. Part students stress self-realization but overlook social responsibility, overemphasize the realization of self value but have poor team cooperation concept, become self-centered but indifferent towards the affairs of nation and collective.

College Chinese teaching and traditional culture education are common responsibilities that should be undertaken by family, college and society. At present, due to the influence of several factors, college students' cultivation of traditional culture has not be paid enough attention. As a result, there is a lack of college Chinese teaching and traditional culture education.

The tide of market economy forces people to pay more attention to economic benefits and ignore the improvement of cultural quality. With the continuous introduction of foreign culture into China, the mainstream culture of our country is experiencing a great impact, resulting into people' confusion in thoughts and actions. Moreover, with the development of internet, college students tend to be fast-reading and are more willing to receive short information. All these phenomena show that in current China, among Chinese colleges and college students, there is no "market" for traditional culture. Therefore, it is urgent to provide a good social environment for college Chinese teaching and traditional culture education.

At present, the requirements for talents from society put more emphasis on technical and academic achievements, which leads to a more specialized and technological discipline construction while neglects the education and cultivation of students' humanistic quality. In some colleges, cultural courses are just considered as secondary supplements to professional curriculum. At the same time, there exist great problems in education contents and methods of related cultural elective courses. For example, in the process of explanation, teachers just work as porters of books. They list points simply and irrigate students without profound explanation and analysis, making students fail to have a deep understanding of traditional culture.

"Moral education from family mainly refers to children's cultivation of right and wrong standards, value concepts, principle of handling affairs from parents. Thus, children will form corresponding moral concepts, moral feelings and habits. Gradually, the adherence to these codes of ethics and conduct become children's conscious moral needs”. Therefore, family is an important place for the formation and development of children's morality. The moral education of family plays a key role in children's formation of moral behavior habits. The level that parents are influenced by traditional culture and importance degree that traditional culture is attached affect directly children's acceptance of traditional culture. However, many contemporary families excessively satisfy children's material life, but ignore the traditional virtues inheritance.

College students are generally indifferent to the excellent traditional culture. They define traditional culture as feudal culture and servile education. As a result, they have poor ability to distinguish traditional culture and easily influenced by western culture, superficial impetuous vulgar culture and undistinguished network culture. 
In a word, from the term of society, families, colleges and college students themselves, college Chinese teaching and traditional culture education confront serious challenges from serious negative factors.

\section{References}

[1] Hasenmuqige. An Analysis of the Application of Traditional Culture in College Chinese Teaching [J]. Examination Weekly, 2018(04)

[2] Ding Juanjuan. On the Blending of College Chinese Teaching and Traditional Culture Education [J]. Emotional Readings, 2017(35)

[3] Yu Haiqun. Research on the Integration and Development of Chinese Excellent Traditional Culture and Chinese Teaching [J]. Forward Position, 2017(09) 